\title{
Feasibility of use of single dose immunization regime in Antibody Induction Method for testing potency of tetanus component in DTP group of vaccines and comparison of validated ELISA with TNT for antibody titration
}

\author{
Vivek Verma ${ }^{1}$, Rakesh Sehgal ${ }^{2 *}$, Ajay K Tahlan ${ }^{3}$, Dinesh K Sood ${ }^{3}$, Vikas Dogar ${ }^{4}$ \\ ${ }^{1}$ Department of Microbiology, Panjab University, Chandigarh, INDIA-160014. \\ ${ }^{2}$ Department of Parasitology, Postgraduate Institute of Medical Education and Research (PGIMER), Chandigarh, \\ INDIA-160012. \\ ${ }^{3}$ Central Research Institute, Kasauli, Himachal Pradesh, INDIA-173204. \\ ${ }^{4}$ Serum Institute of India, Pune, INDIA. \\ * Corresponding Author \\ Prof. Rakesh Sehgal, (MD, DNB, MAMC). \\ ${ }^{2}$ Department of Parasitology, Postgratuate Institute of Medical Education and Research (PGIMER), Chandigarh, \\ INDIA-160012. \\ Telephone: +91-172-2755168 \\ E-Mail: sehgalrksh@gmail.com
}

Received: 12 January 2009; $\mid$ Revised: 18 February 2009; $\mid$ Accepted: 2 March 2009

\section{Abstract}

Conventionally, for estimation of potency of tetanus toxoid by Antibody Induction Method (AIM), two doses $\left(1 / 10^{\text {th }}\right.$ of single human dose/dose) of tetanus toxoid given on $0^{\text {th }}$ and $28^{\text {th }}$ day, injected subcutaneously into guinea pigs has been recommended. But this assay has a serious drawback of 'booster effects' as the animal is immunized on two occasions besides usage of large number of animals. Hence, feasibility of using single dilution given at single occasion was assessed. For this a three dilution regime was used wherein three dilutions of the standard and test tetanus toxoid (TT) were injected subcutaneously into guinea pigs. Postimmunization sera were raised at $4^{\text {th }}$ and $6^{\text {th }}$ week and titrated by in-vivo Toxin Neutralization Test (TNT) done in mice and in-vitro indirect enzyme-linked immunosorbent assay (ELISA). For TNT, L+/10 doses of toxin combined with different concentrations of serum samples were inoculated into mice for anti-tetanus antitoxin detection. It was found that if the animal was bled at $4^{\text {th }}$ week post-immunization, anti-tetanus antibody titers as shown by ELISA were 4-5 times higher than the titers estimated by TNT while at $6^{\text {th }}$ week ELISA and TN titers were comparable $\left(\mathrm{r}^{2}=0.999\right)$. When the time of bleeding, post-immunization, was increased from $4^{\text {th }}$ to $6^{\text {th }}$ week, a 5 fold increase in neutralizing antibody titer was seen. Also, standardized ELISA was found to be of high validity and can be used as an alternate for evaluation of anti-tetanus neutralizing antibodies, thus permitting the in-vitro evaluation of the tetanus antitoxin. Moreover, besides saving mice, ELISA saves five days required for TNT and the pressure on the laboratory is significantly reduced. 
Keywords: Double-Dose Single-Dilution; Single-Dose Single-Dilution; Tetanus Toxoid; ELISA;

Toxin Neutralization Test; Validation; Time of bleeding.

\section{Introduction}

Neonatal Tetanus is a leading cause of newborn mortality in developing countries $[1,2$, 3 ] and ranks second only to measles amongst the vaccine preventable diseases that are included in the Expanded Programme on Immunization (EPI) $[3,4,5]$. No immunity is provided by very low amount of toxin that is capable in establishing the disease. Hence, as soon as the patient is exposed to the risk of developing tetanus active immunization for development of appropriate immune response should be done [6]. Due to ubiquitous presence of spores of Clostridium tetani eradication of tetanus is not feasible however, control of the disease by wide coverage of the tetanus toxoid and better conditions of hygiene is possible [4].

For immunization purpose two types of tetanus toxoid preparations i.e. adsorbed (aluminum salt precipitated) toxoid and fluid toxoid are available. Even though seroconversion rates with the two formulations are about equal, the adsorbed toxoid is preferred because the antitoxin response to adsorbed toxoid reaches higher titers and is longer lasting than to the fluid toxoid [6]. In groups where tetanus is an occupational hazard, adsorbed tetanus toxoid (TT) is used prophylactically while in pregnant women it is used in order to prevent neonatal as well as puerperal tetanus. Immunization programmes aim at inducing the desired protective level of 0.01 $\mathrm{IU} / \mathrm{ml}[6,7]$ in the vaccinee, of tetanus antibodies, that appear in the blood following vaccination. Thus determination of tetanus antibody level permits the evaluation of effectiveness of a toxoid preparation and various parameters of immunization $[8,9]$.

Methods for potency testing as recommended by various authorities [10,11, 12, 13] differ in many respects (Table 9) and despite the success of tetanus vaccines for human use, worldwide harmonization, regarding the methods for testing vaccine potency is yet to be obtained [10].
According to the $\mathrm{WHO}$, one of the essential steps in the quality control of vaccine for human use containing tetanus toxoid is the potency assay [14].

Potency of tetanus toxoid vaccines can be checked by two methods: i) Challenge method [14] and ii) Antibody Induction Method (AIM) [13]. Irrespective of the method used, induction of an antitoxin response in laboratory animals and the measurement of that response are two vital steps of the method in assessing the potency of the tetanus toxoid vaccines [15]. In both the above mentioned methods induction of the immune response is by immunization of the animals with a suitable antigenic preparation. In challenge method induction is only once i.e. animal is immunized at one occasion only, while in AIM animal is immunized on two occasions. In challenge method measurement of the induced response is by challenging the immunized animals 28 days after immunization with a suitable toxin preparation, while in AIM measurement of the induced response is by some suitable antibody titration method $[13,16]$ performed on the sera raised from the immunized animals.

Power of any potency assay to discriminate between high and low quality vaccines is diminished by multi injection immunization scheme [17]. Hence booster doses are not preferred for assessment of the potency of tetanus vaccines [18]. For this reason challenge method may be preferred over AIM as animal immunization is done only once and same animals are used for induction and measurement of the immune response to the vaccine. Moreover using the same animals saves upon the mice required in the AIM for antibody titration [13]. However, from a very large number of costly animals, challenge method provides only a small amount of quantal information i.e. whether immunized animals are protected or not [15]. Hence, despite being a gold standard test and despite the fact that all international standards of tetanus toxoid are calibrated using challenge method performed in 
guinea pigs [10] this method is not preferred. On the other hand from the AIM greater amount of quantitative information i.e. amount of antitoxin induced by the antigen is obtained [15]. But in AIM immunization is done on two occasions [13] due to which batch to batch variability cannot be assessed [18].

Existence of assays for detection of functional and neutralizing antibodies to toxin made it possible to establish correlation with protection and with surrogate methods for antibodies such as ELISA, using relevant samples from suitable animal model [19]. Gupta and Siber [20] have shown that tetanus specific IgG antibodies measured by ELISA appear in sera of guinea pigs at ninth day of inoculation when there were no neutralizing antibodies (below the lowest detection level of $0.005 \mathrm{AU} / \mathrm{ml})$. IgG antibodies, which appeared during the early course of immunization may be of low affinity and low avidity. These antibodies bound in ELISA but did not neutralize tetanus toxin. At two weeks after injection of mice with TT (fluid or adsorbed), TN antibody levels were very low whereas antitetanus toxoid IgG antibody levels by ELISA were 35 to 40 times higher than the TN titers [20]. Hence, bleeding time post immunization is critical, as too early time post-immunization will induce antibody response that may not correlate with functional antibody response [20, 21]. Even though, it is reported in various studies $[18,20$, 21] that increasing time post immunization reduced difference between responses to diphtheria and tetanus as well as reduced differences between functional and total antibodies induced by these antigens but too much increase in time post immunization is costly and impractical for batch release purpose [18].

Hence in light of these observations present study has been undertaken to assess the feasibility of use of single dose immunization regime in AIM to check for optimum time of bleeding for sera raising besides comparing ELISA with TNT as a method for antibody titration.

\section{Materials and methods}

\subsection{Materials}

Am. J. Biomed. Sci. 2009, 1(2), 143-156; doi: 10.5099/aj090200143
2.1.1. Tetanus Toxin: Tetanus Toxin (batch no. 18/93) was obtained from National Control Laboratory (NCL), Central Research Institute (CRI), Kasauli, Himachal Pradesh (HP), India. The toxin was provided in liquid form. The toxin solution was distributed in small aliquots and stored at $-20^{\circ} \mathrm{C}$.

2.1.2. Standard antitoxins: National Reference Standard (NRS) of tetanus antitoxin (Batch No. $8 / 05)$ of equine origin was obtained from NCL, CRI, Kasauli, HP, India. The standard was supplied at a unitage of $10 \mathrm{IU} / \mathrm{ml}$.

2.1.3. Standard Toxoid: WHO standard of tetanus toxoid (WHOIS) adsorbed on aluminium phosphate was obtained from National Institute of Biological Standardization. The standard toxoid was obtained in freeze dried form at a unitage of $340 \mathrm{IU} / \mathrm{vial}$ as defined from guinea pig challenge method [13].

2.1.4. Test vaccine: DTwP vaccine containing diphtheria toxoid ( $\geq 30 \mathrm{IU} /$ dose), tetanus toxoid ( $\geq$ $40 \mathrm{IU} /$ dose) and whole cell pertussis (wP) ( $\geq 4$ $\mathrm{IU} /$ dose) adsorbed onto $\mathrm{AlPO}_{4}(\geq 1.5 \mathrm{mg} / \mathrm{dose})$ containing $0.01 \%$ thiomersal as preservative was used in the present study. Vaccine was obtained from the NCL, CRI, Kasauli, HP, India.

2.1.5. Animals: Guinea pigs (250-350 gm) of either sex were used in the present study. Male and female animals were kept separate and various dilutions of vaccine were allocated randomly to different groups. All animals were identified individually using a suitable colour code system. Mice (17-22 gm; NIH) of either sex were used in the study. All animals were obtained from the experimental animal division, national animal house, CRI, Kasauli, HP, India.

All animals were handled humanly and all animal experiments were performed as per the regulations of the Animal Ethical Committee, CRI, Kasauli, HP, India.

2.1.6. Diluent: All toxin dilutions were made in $1 \%$ sterile peptone water $(\mathrm{pH} 7.2-7.4)$ and all serum dilutions were made in sterile normal saline (NS).

(C) 2009 by NWPII. All rights reserved. 


\subsection{Methods}

2.2.1. Study Design (Table 1): A group of 18 guinea pigs each was immunized subcutaneously $(1.0 \mathrm{ml})$ with 3 serial two-fold dilutions of the test vaccine and WHOIS. Freeze dried WHOIS was diluted appropriately from which further two fold dilutions were made. First dilution of test vaccine contained half the single human dose (SHD) while standard toxoid contained $40 \mathrm{IU} / \mathrm{ml}$ of tetanus toxoid adsorbed on to aluminium phosphate.

All animals were immunized at one occasion only. Nine animals from each dilution group were bled at $4^{\text {th }}$ week while rest of 9 were bled at $6^{\text {th }}$ week after immunization. Another group of 9 guinea pigs was immunized on two occasions $\left(0^{\text {th }}\right.$ and $28^{\text {th }}$ day) using $1 / 20$ dilution of adsorbed Standard TT containing $1 / 10^{\text {th }}$ of SHD and bled at $6^{\text {th }}$ week after immunization [13]. All separated sera were inactivated at $56^{\circ} \mathrm{C} / 1 / 2 \mathrm{hr}$ and stored at $20^{\circ} \mathrm{C}$ until tested. Equal volumes of sera raised after two immunizations with standard TT were pooled to get a pooled serum sample (PS). Antitoxin level of PS was determined by TNT performed in mice against NRS of tetanus antitoxin (specified in material section) and unitage was expressed in IU/ml. Calibrated PS was labeled as In-house working standard and was used as a positive control to determine anti-tetanus response in individual animal serum by ELISA as well as for the titration of test serum samples for anti-tetanus anti-toxin by TNT.

\begin{tabular}{|c|c|c|c|}
\hline \multicolumn{2}{|c|}{ Immunization } & $\begin{array}{c}\text { AПM } \\
(\mathbb{P}, 1996)\end{array}$ & Study Method \\
\hline \multicolumn{2}{|c|}{ Animal species/number } & Guinea pigs/9 & Guinea pigs/18 \\
\hline \multicolumn{2}{|c|}{ Weight range/sex } & $\begin{array}{l}250-350 \mathrm{gm} / \mathrm{either} \\
\text { sex }\end{array}$ & $\begin{array}{l}250-350 \mathrm{gm} / \mathrm{either} \\
\text { sex }\end{array}$ \\
\hline \multicolumn{2}{|c|}{ Immunizing route } & $1.0 \mathrm{ml} / \mathrm{sc}$ & $1.0 \mathrm{ml} / \mathrm{sc}$ \\
\hline \multirow{2}{*}{$\begin{array}{l}\text { Immunizing * } \\
\text { dose }\end{array}$} & $\begin{array}{c}\text { 1st } \\
\text { dose }\end{array}$ & $1 / 20^{\# \text { th dilution }}$ & \multirow{2}{*}{$\begin{array}{c}1 / 4 @, 1 / 8,1 / 16 \\
\text { Dilution of Standard } \\
\text { TT and Test TT }\end{array}$} \\
\hline & $\begin{array}{l}\text { 2nd } \\
\text { dose }\end{array}$ & $1 / 20$ th dilution & \\
\hline \multicolumn{2}{|c|}{ Bleeding (After 2nd dose) } & $\begin{array}{l}\text { Not later than } 2 \\
\text { weeks }\end{array}$ & $\begin{array}{c}9 \text { animals at } 4 \text { th and } \\
6 \text { th week from each } \\
\text { dilution }\end{array}$ \\
\hline \multicolumn{2}{|c|}{ TNT (individual sera) } & $\begin{array}{l}\text { In mice (at } \mathrm{L}+10 \\
\text { dose of Toxin) }\end{array}$ & $\begin{array}{c}\text { In mice (at } L+10 \\
\text { dose) and by ELISA }\end{array}$ \\
\hline \multicolumn{2}{|c|}{ Requirements } & $\begin{array}{c}2 / 3 \text { of Guinea pig } \\
\text { sera should contain } \geq \\
0.5 \mathrm{IU} / \mathrm{ml} \text { of Tetanus } \\
\text { antitoxin. }\end{array}$ & \\
\hline
\end{tabular}

Table 1. Method adopted in the present study and its comparison to the already established AIM. In the present study two sets of animals were immunized subcutaneously (sc). One set with 3 dilutions of standard TT and test TT at one occasion and other with one dilution (1/20) of standard TT on two occasions by conventional AIM. Sera raised from the animals immunized on two occasions was pooled, its antitoxin levels titrated by TNT done in mice against NRS and labeled as In-house working standard (unitage expressed in IU/ml). ${ }^{\# 1} 1 / 10^{\text {th }}$ of SHD. ${ }^{\circledR} 1 / 2$ of SHD in case of test TT and $40 \mathrm{IU} / \mathrm{ml}$ in case of Standard TT. 
2.2.2. Estimation of Tetanus antibody titer in the individual guinea pig sera by toxin neutralization test performed in mice

\subsubsection{Determination of $\mathrm{L}+/ 10$ dose of Tetanus}

toxin: $\mathrm{L}+/ 10$ test dose of toxin is the least amount of toxin which when mixed with 0.1 unit of standard antitoxin in dose per mouse, causes death of all mice injected, in four days. L+/10 dose of the tetanus toxoid were determined as per the method described elsewhere [13].

\subsubsection{Toxin Neutralization (TN) Test: The TN} test was performed at $\mathrm{L}+/ 10$ level of tetanus toxin as per the method described earlier [20]. Briefly, tetanus toxin was diluted in $1 \%$ peptone water to 4 $\mathrm{L}+/ 10$ doses per $\mathrm{ml}$. Then various dilutions of NRS of tetanus antitoxin or serum samples were mixed with eight $\mathrm{L}+/ 10$ doses of toxin. The volume was made upto $4.0 \mathrm{ml}$ with normal saline (Table 2). The toxin-antitoxin or toxin-serum mixtures were incubated at room temperature for 1 hour. Then 6 mice each, were injected with 0.5 $\mathrm{ml} /$ subcutaneously from each mixture. Mice were observed for 5 days for tetanic symptoms or death. The unitage of serum samples were calculated against the standard antitoxin expressed in IU/ml.

\begin{tabular}{|c|c|c|c|c|c|c|c|}
\hline \multirow{2}{*}{$\begin{array}{l}\text { Unitage } \\
\text { tested } \\
\text { for } \\
\left(\mathrm{IU}^{\$} / \mathrm{ml}\right)\end{array}$} & \multicolumn{3}{|c|}{ Mix injected in each animal } & \multicolumn{3}{|c|}{$\begin{array}{l}\text { Mixture made for } 10 \\
\text { animals, injected } 6\end{array}$} & \multirow{2}{*}{ Observation } \\
\hline & $\begin{array}{l}\operatorname{Toxin}^{\star} \\
\text { (ml) }\end{array}$ & $\begin{array}{l}\text { Anti } \\
\text { Toxin } \\
\text { Unit }\end{array}$ & $\begin{array}{l}\text { Volume } \\
\text { (ml) }\end{array}$ & $\begin{array}{l}\text { Toxin } \\
\text { (10 test } \\
\text { doses in } \\
\text { ml) }\end{array}$ & $\begin{array}{l}\text { Anti } \\
\text { toxin } \\
\text { (ml) }\end{array}$ & $\begin{array}{l}\mathrm{N} / \mathrm{S} \\
(\mathrm{ml})\end{array}$ & \\
\hline 0.12 & 0.00475 & 0.12 & 0.5 & 2.5 & 1.20 & 1.30 & $\begin{array}{c}\text { All mice } \\
\text { survived with } \\
\text { symptoms of } \\
\text { Tetanus }\end{array}$ \\
\hline 0.11 & 0.00475 & 0.11 & 0.5 & 2.5 & 1.10 & 1.40 & -do- \\
\hline 0.10 & 0.00475 & 0.10 & 0.5 & 2.5 & 1.00 & 1.50 & $\begin{array}{l}50 \% \text { of mice } \\
\text { died and rest } \\
\text { survived with } \\
\text { symptoms of } \\
\text { Tetanus }\end{array}$ \\
\hline 0.09 & 0.00475 & 0.09 & 0.5 & 2.5 & 0.90 & 1.60 & $\begin{array}{l}\text { All mice died in } \\
5 \text { day period }\end{array}$ \\
\hline 0.08 & 0.00475 & 0.08 & 0.5 & 2.5 & 0.80 & 1.70 & -do- \\
\hline
\end{tabular}

Table 2. Titration of Standard Tetanus Antitoxin at L+/10 dose of Tetanus Toxin. ${ }^{\$}$ International Unit, *Toxin was diluted in peptone water, ${ }^{*}$ Antitoxin diluted in NS.

2.2.3. Enzyme-linked immunosorbent assay (ELISA): For titration of guinea pig sera antibody specific indirect ELISA was standardized by checkerboard titrations to give optimum results in our laboratory. According to standardized procedure column 1-10 of microtiter plates (NuncAm. J. Biomed. Sci. 2009, 1(2), 143-156; doi: 10.5099/aj090200143 immunoplate, Maxisorp Cat. No. 442409) were coated with $100 \mu \mathrm{l}$ of purified tetanus toxoid (4.34 $\mathrm{Lf} / \mathrm{ml})$ at $4{ }^{\circ} \mathrm{C}$ /overnight in coating buffer $(0.05 \mathrm{M}$ bicarbonate buffer, $\mathrm{pH}$ 9.6). In column 1 and 2 Inhouse working standard (PS) was diluted serially and columns 3 through 10 were used for 2 fold (C) 2009 by NWPII. All rights reserved. 
dilutions of test serum samples. Columns 11 and 12 were used for various controls viz. -ve serum control, plate control, +ve serum control, buffer control, conjugate control and substrate control. Each sample was titrated in duplicate and on two occasions. After incubation for 2 hours at $37^{\circ} \mathrm{C}$ $100 \mu 1$ Horse Radish Peroxidase (HRP) labeled rabbit anti-guinea pig IgG (Sigma, Cat. No. A5545) diluted in PBS containing 0.5\% Tween 20 and $1 \% \mathrm{BSA}$ were added to plates. The plates were incubated at $37^{\circ} \mathrm{C}$ for 1 hour. Finally $100 \mu \mathrm{l}$ substrate solution made by dissolving $\mathrm{o}-$ phenylenediamene dihydrochloride (OPD) + urea adduct tablets (Sigma, Cat. No. P6662 \& U8879 respectively) in appropriate volume of $\mathrm{dH}_{2} \mathrm{O}$ was added and colour was allowed to develop for $1 / 2$ an hour at room temperature in dark. The plates were read in an ELISA reader at $450 \mathrm{~nm}$ wavelength after stopping the reaction with $50 \mu \mathrm{l}$ of $1 \mathrm{~N} \mathrm{H}_{2} \mathrm{SO}_{4}$. The unitage of serum samples was expressed in IU/ml against the In-house working standard. Cut off value for ELISA was calculated as mean OD of -ve control wells +2 (SD of the means of OD of -ve control wells) [22]. After each incubation, prior to addition of subsequent analyte a washing step was performed to remove unbound analyte using washing buffer (PBS+0.5\% Tween 20) wherein plate was washed thoroughly 3 times with the washing buffer.

\begin{tabular}{|c|c|c|c|c|c|c|c|c|c|c|c|c|}
\hline \multirow[b]{2}{*}{ Preparation } & \multirow[b]{2}{*}{$\begin{array}{c}\text { Bleeding } \\
\text { time }\end{array}$} & \multirow[b]{2}{*}{ Dilution } & \multicolumn{2}{|c|}{$\mathrm{GMT}^{\prime}(\mathrm{IU} / \mathrm{ml})$} & \multirow[b]{2}{*}{$\begin{array}{c}\text { Bleeding } \\
\text { time }\end{array}$} & \multirow[b]{2}{*}{ Dilution } & \multicolumn{2}{|c|}{ GMT (IU/ml) } & \multicolumn{4}{|c|}{ Ratio } \\
\hline & & & TNT $^{\phi}$ & ELISA & & & TNT & ELISA & $\begin{array}{c}\text { TNT } \\
6 / 4 \\
\text { week }\end{array}$ & $\begin{array}{c}\text { ELISA } \\
6 / 4 \\
\text { week }\end{array}$ & $\begin{array}{c}\text { ELISAITNT } \\
4 \text { weeks }\end{array}$ & $\begin{array}{l}\text { ELISAITNT } \\
6 \text { weeks }\end{array}$ \\
\hline \multirow{2}{*}{$\begin{array}{l}\text { Standard } \\
\text { TT* }^{*}\end{array}$} & \multirow[b]{2}{*}{4 weeks } & $1 / 4$ & 0.53 & 2.72 & \multirow[b]{2}{*}{6 weeks } & $1 / 4$ & 2.62 & 3.17 & $4.95: 1$ & $1.17: 1$ & $5.13: 1$ & $1.20: 1$ \\
\hline & & $1 / 8$ & 0.45 & 2.52 & & $1 / 8$ & 2.43 & 2.94 & $5.34: 1$ & $1.17: 1$ & $5.52: 1$ & $1.21: 1$ \\
\hline \multirow{3}{*}{ Test TT@ } & \multirow{3}{*}{4 weeks } & $1 / 4$ & 0.67 & 2.33 & \multirow{3}{*}{6 weeks } & $1 / 4$ & 1.08 & 1.59 & $1.63: 1$ & $0.68: 1$ & $3.49: 1$ & $1.47: 1$ \\
\hline & & $1 / 8$ & 0.37 & 1.59 & & $1 / 8$ & 0.49 & 1.58 & $1.33: 1$ & $0.99: 1$ & $4.32: 1$ & $3.23: 1$ \\
\hline & & $1 / 16$ & 0.32 & 1.47 & & $1 / 16$ & 0.55 & 1.36 & $1.74: 1$ & $0.93: 1$ & $4.66: 1$ & $2.48: 1$ \\
\hline
\end{tabular}

Table 3 shows various formulations, bleeding time, dilutions used, respective titers and the various ratios derived from the data. TN titers were estimated against NRS (National Refrence Standard) and ELISA titers against In-house working standard of tetanus antitoxin. *WHOIS $1 / 4$ dilution contained 40 $\mathrm{IU} / \mathrm{ml},{ }^{\circledR}$ Test toxoid contained half the single human dose (SHD) in $1 / 4$ dilution, ${ }^{\#}$ Geometric Mean Titer ( $\mathrm{n}=9$ ), ${ }^{\$}$ Toxin Neutralization Test.

\section{Results}

3.1. TN Titers of guinea pig sera: Guinea pig sera raised after single immunization with different dilutions $(1 / 4,1 / 8$ and $1 / 16)$ of tetanus toxoid (standard and test) were evaluated for antitetanus antibody titer by TNT using $\mathrm{L}+/ 10$ dose of tetanus toxin. The geometric mean titers (GMTs) of 9 six week guinea pig sera at 1/4, 1/8 and $1 / 16$ dilutions were 2.62, 2.43 and 0.36 respectively. While GMTs of 9 four weeks sera at the respective dilutions were $0.53,0.45$ and 0.33 (Table 3 ). At dilutions $1 / 4$ and $1 / 8$ approximately 5 fold increase in TN antibody titer, when the time post immunization was increased from 4 to 6 weeks, was seen. TN titers of sera raised 4 weeks Am. J. Biomed. Sci. 2009, 1(2), 143-156; doi: 10.5099/aj090200143 after single dose of adsorbed test TT at 1/4, 1/8 and $1 / 16$ dilutions were $0.67,0.37$ and $0.31 \mathrm{IU} / \mathrm{ml}$ respectively while TN titers of 6 weeks sera at respective dilutions were $1.08,0.49$ and 0.55 $\mathrm{IU} / \mathrm{ml}$. From this also, it is clear that at dilution $1 / 4$ there was a 3 fold increase in $\mathrm{TN}$ titer when bleeding time was increased to 6 weeks. However at dilutions $1 / 8$ and $1 / 16$ the ratio remained almost unchanged (Table 3) which suggested lower antigenic content at these dilutions that was not able to induce increase in neutralizing antibody titer.

3.2. ELISA titer of guinea pig sera: All guinea pig sera, which were titrated by TNT, were also titrated by standardized indirect ELISA. All sera (C) 2009 by NWPII. All rights reserved. 
were titrated in duplicate on two occasions against the In-House working standard (PS). ELISA titers of sera raised 4 weeks after single dose of adsorbed standard TT at $1 / 4,1 / 8$ and $1 / 16$ dilutions were $2.72,2.5$ and $1.0 \mathrm{IU} / \mathrm{ml}$ respectively, while ELISA titers at respective dilutions 6 weeks after immunization were $3.17,2.94$ and $1.08 \mathrm{IU} / \mathrm{ml}$ (Table 3). There was not any substantial difference between the ELISA anti-tetanus anti-toxin titers of $6^{\text {th }}$ and $4^{\text {th }}$ week guinea pig sera, as ELISA/TNT ratio was close to unity. ELISA titers of sera raised 4 weeks after single dose of adsorbed test tetanus toxoid at $1 / 4,1 / 8$ and $1 / 16$ dilutions were 2.33, 1.59 and $1.47 \mathrm{IU} / \mathrm{ml}$ respectively. While ELISA titers of 6 weeks sera at respective dilutions were $1.59,1.58$ and $1.36 \mathrm{IU} / \mathrm{ml}$ (Table $3)$. Here also the ratio of 6 to 4 week antibody titer was close to unity.

\begin{tabular}{|c|c|c|c|c|c|c|}
\hline \multirow[t]{2}{*}{ Assay No. } & \multirow[t]{2}{*}{ Plate No. } & \multicolumn{5}{|c|}{$\begin{array}{l}\text { Mean OD value } \\
\text { Serum samples }\end{array}$} \\
\hline & & 1 & 2 & 3 & 4 & 5 \\
\hline \multirow{5}{*}{1} & 1 & 1.122 & 0.851 & 1.103 & 0.904 & 1.027 \\
\hline & 2 & 1.085 & 0.842 & 1.106 & 0.897 & 1.009 \\
\hline & Mean & 1.1035 & 0.8465 & 1.104 & 0.900 & 1.018 \\
\hline & SD & 0.0185 & 0.0045 & 0.0015 & 0.0035 & 0.009 \\
\hline & $\% \mathrm{CV}$ & 0.016 & 0.531 & 1.35 & 3.8 & 0.88 \\
\hline \multirow{5}{*}{2} & 3 & 1.294 & 0.419 & 0.947 & 0.470 & 0.908 \\
\hline & 4 & 1.282 & 0.318 & 0.890 & 0.503 & 0.937 \\
\hline & Mean & 1.288 & 0.400 & 0.918 & 0.486 & 0.922 \\
\hline & SD & 0.006 & 0.019 & 0.028 & 0.0165 & 0.0145 \\
\hline & $\% \mathrm{CV}$ & 4.65 & 4.75 & 3.10 & 3.39 & 1.57 \\
\hline \multicolumn{7}{|c|}{ Overall, $n=4$} \\
\hline & Mean & 1.195 & 0.623 & 1.025 & 0.693 & 0.970 \\
\hline & $\mathrm{SD}^{\Theta}$ & 0.092 & 0.223 & 0.0785 & 0.207 & 0.048 \\
\hline & $\% \mathrm{CV}^{\$}$ & 7.69 & 35.8 & 7.65 & 29.8 & 4.94 \\
\hline
\end{tabular}

Table 4 shows the precision in terms of repeatability and reproducibility of the ELISA. To evaluate the precision of assay under the normal operating conditions 2 assays were performed on 2 non-consecutive days. Each assay was conducted on 2 identical plates with five serum samples on each plate. Each serum sample was titrated in duplicate. ${ }^{\circledR}$ Standard deviation, ${ }^{\$}$ coefficient of variation.

\subsection{Correlation between TN and ELISA Titers} of guinea pig sera: TN and ELISA titer of sera raised at different days of bleeding and at different dilutions were compared with each other to obtain the correlation coefficient. In case of sera raised after immunization with standard TT at 4 weeks there was good correlation between ELISA and
TN titers (0.968) even though ELISA titers were 3-5 times higher than the TN titers (Table 3). However at 6 weeks post-immunization the correlation increased further $\left(\mathrm{r}^{2}=0.999\right)$ as the ELISA to TN titers equaled each other (Table 3 ). But in case of sera raised after immunization with test TT, at $4^{\text {th }}$ week, like in case of standard TT, 
ELISA and TN titers showed good correlation $\left(r^{2}=0.999\right)$ even though ELISA titers were 3-4 times higher than TN titers while at $6^{\text {th }}$ week correlation was $0.433\left(=r^{2}\right)$. This might be due to low antigenic content at $1 / 8$ and $1 / 16$ dilutions, which was not able to induce any substantial response in immunized animals, while at $1 / 4$ dilution a 3 fold increase in TN titer was observed due to which ELISA to TN ratio almost became unity.

\subsection{Validation of ELISA}

\subsubsection{Limit of detection (LOD) and limit of} quantitation (LOQ): The standardized ELISA was found to be highly sensitive and able to detect antibodies at a very low concentration. Minimum level of detection (LOD $=\mathrm{OD}$-ve control wells) was calculated as $0.0002 \mathrm{IU} / \mathrm{ml}$ while the minimum level of quantification $(\mathrm{LOQ}=\mathrm{OD}$-ve control wells +3 $\mathrm{SD})$ was calculated to be $0.0005 \mathrm{IU} / \mathrm{ml}$ for tetanus indirect ELISA.
3.4.2. Precision: It is the degree of agreement among individual test results. To evaluate the precision of assay under the normal operating conditions, 2 assays on non-consecutive days were performed. Each assay was conducted on 2 identical plates with five serum samples on each plate. Each serum sample was titrated in duplicate.

3.4.2.1. Repeatability (Within-run precision): The mean OD, standard deviation (SD) and \% coefficient of variation (CV) of the duplicate sample dilutions of the 5 sera were determined from two assays for a total of 4 plates. Over $90 \%$ of the duplicate dilutions had a $\mathrm{CV}<10 \%$ (data not shown), which indicated well to well precision of the assay. The plate to plate precision was evaluated by determining the mean OD of the 5 sera from 2 plates (per day) repeated on 2 nonconsecutive days. $\mathrm{CV}$ of all five serum samples of the plate-to-plate, within-run were below 5\% (Table 4). The results demonstrated that the within-run precision of the ELISA was excellent.

\begin{tabular}{|c|c|c|c|}
\hline Incubatory condition & $\begin{array}{c}37^{\circ} \mathrm{C} / 3 \text { hours }-4^{\circ} \mathrm{C} / \\
\text { overnight }\end{array}$ & $4^{\circ} \mathrm{C}$ overnight & $37^{\circ} \mathrm{C} / 3$ hours \\
\hline $\mathrm{OD}_{450}$ & 1.661 & 1.726 & 1.901 \\
\hline Mean of $\mathrm{OD}_{450}$ & \multicolumn{3}{|c|}{1.762} \\
\hline $\mathrm{SD}^{9}$ & \multicolumn{3}{|c|}{0.101} \\
\hline$\% \mathrm{CV}^{\$}$ & \multicolumn{3}{|c|}{5.73} \\
\hline
\end{tabular}

Table 5 shows the robustness of ELISA. Robustness was demonstrated with respect to the incubation temperature for antigen coating. Three incubatory conditions viz. $37^{\circ} \mathrm{C} / 3 \mathrm{hrs}$ followed by $4^{\circ} \mathrm{C}$ overnight, $4^{\circ} \mathrm{C}$ overnight and $37^{\circ} \mathrm{C}$ were chosen. ${ }^{\circledR}$ Standard Deviation, ${ }^{\$}$ Coefficient of variation.

\subsubsection{Reproducibility (Between-run} precision): The day-to-day (between-run) CV for 4 plates from 2 days is shown in Table 4 . Three out of five serum samples had a day-to-day CV below 20\%, while the day-to-day CV for two serum samples was greater than $20 \%$.

3.4.3. Robustness: It is the capacity of an assay to remain unaffected by deliberate changes in assay parameters.
3.4.3.1. Effect of incubatory temperature on antigen coating: To check for robustness in terms of incubatory conditions, antigen coating was done at three different conditions i.e. $37^{\circ} \mathrm{C} / 3 \mathrm{hrs}$ followed by $4^{\circ} \mathrm{C} /$ overnight, $37^{\circ} \mathrm{C} / 3 \mathrm{hrs}$ and $4^{\circ} \mathrm{C}$ /overnight. For one incubatory condition assay was carried out on two plates and assay for different incubatory condition were carried on different days. The $\% \mathrm{CV}$ as obtained for 3 different assays on 3 different days was $5.73 \%$ 
(Table 5). Hence, different incubation conditions for antigen coating did not affect the outcome of the assay substantially and hence ELISA is robust in terms of coating-time and temperature conditions.

\begin{tabular}{|c|c|c|c|c|c|c|}
\hline & \multicolumn{3}{|c|}{ +ve serum } & \multicolumn{3}{|c|}{-ve serum $\&$} \\
\hline & \multirow[t]{2}{*}{ Unblocked } & \multicolumn{2}{|c|}{ Blocked } & \multirow[t]{2}{*}{ Unblocked } & \multicolumn{2}{|c|}{ Blocked } \\
\hline & & $\operatorname{BSA}(1 \%)$ & $\operatorname{SM}(5 \%)$ & & $\operatorname{BSA}(1 \%)$ & SM $(5 \%)$ \\
\hline $\mathrm{OD}_{450}$ & 1.448 & 1.441 & 1.280 & 0.252 & 0.217 & 0.137 \\
\hline $\begin{array}{l}\text { Mean } \\
\mathrm{OD}_{450}\end{array}$ & \multicolumn{2}{|c|}{1.4445} & & \multicolumn{2}{|c|}{0.2345} & \\
\hline $\mathrm{SD}^{*}$ & \multicolumn{2}{|c|}{0.0035} & & \multicolumn{2}{|c|}{0.0175} & \\
\hline$\% \mathrm{CV}^{\#}$ & \multicolumn{2}{|c|}{0.242} & & \multicolumn{2}{|c|}{7.4} & \\
\hline & & & & & & \\
\hline $\begin{array}{l}\text { Mean } \\
\text { OD }_{450}\end{array}$ & & \multicolumn{2}{|c|}{1.3605} & & \multicolumn{2}{|c|}{0.177} \\
\hline SD & & \multicolumn{2}{|c|}{0.0805} & & \multicolumn{2}{|c|}{0.04} \\
\hline$\% \mathrm{CV}$ & & \multicolumn{2}{|c|}{5.9} & & \multicolumn{2}{|c|}{22.5} \\
\hline
\end{tabular}

Table 6 shows the effect of blocking the non-specific sites on ELISA plate using bovine serum albumin (BSA;1\%) and skimmed milk (SM; 5\%) (details in text). "standard deviation, "coefficient of variation,

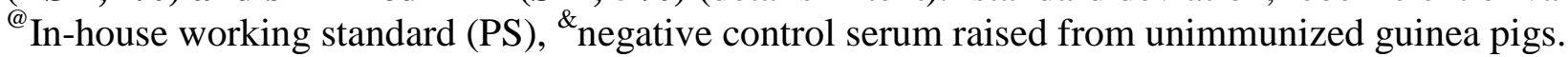

\begin{tabular}{|c|c|c|c|c|c|c|c|}
\hline \multirow[t]{2}{*}{$\begin{array}{l}\text { Sample } \\
\text { Dilution }\end{array}$} & \multicolumn{7}{|c|}{$\begin{array}{c}\text { Mean OD450 }(n=3) \\
\text { Serum Samples }\end{array}$} \\
\hline & $\mathrm{PS}^{*}$ & 1 & 2 & 3 & 4 & 5 & 6 \\
\hline $1: 64$ & 1.753 & 1.026 & 1.001 & 0.822 & 1.582 & 1.865 & 1.583 \\
\hline $1: 128$ & 1.5615 & 0.813 & 0.797 & 0.659 & 1.426 & 1.754 & 1.373 \\
\hline $1: 256$ & 1.312 & 0.528 & 0.555 & 0.422 & 1.257 & 1.634 & 1.130 \\
\hline $1: 512$ & 1.102 & 0.381 & 0.400 & 0.327 & 0.965 & 1.433 & 0.811 \\
\hline $1: 1024$ & 0.780 & 0.263 & 0.288 & 0.209 & 0.669 & 1.14 & 0.548 \\
\hline $1: 2048$ & 0.527 & 0.224 & 0.211 & 0.172 & 0.448 & 0.846 & 0.362 \\
\hline $1: 4096$ & 0.339 & 0.159 & 0.170 & 0.129 & 0.301 & 0.625 & 0.237 \\
\hline $1: 8192$ & 0.209 & 0.178 & 0.169 & 0.136 & 0.246 & 0.400 & 0.186 \\
\hline
\end{tabular}

Table 7 shows the linearity of ELISA demonstrated by calculating mean $\mathrm{OD}_{450}$ from different dilution levels. To verify the linearity of the assay, 6 randomly chosen guinea pig serum samples were tested, evaluated and compared with standard serum (PS) and with each other. *Pooled Sera.

3.4.3.2. Effect of non-specific blocking: To check the effect of non-specific blocking with $1 \%$ BSA for $1 \mathrm{hr}$ an assay on two plates was carried out on one day. On one plate in-house working standard (PS) and on other pooled -ve control serum was titrated. Microtiter plates were coated with $4.34 \mathrm{Lf} / \mathrm{ml}$ of tetanus toxoid. Then six columns were subjected to blocking with $1 \% \mathrm{BSA}$ for 1 hour at $37^{\circ} \mathrm{C}$ while rests of six columns were left unblocked. Then plate was washed thoroughly 3 times with washing buffer and rest of procedure completed using PS sample. Mean OD for blocked 
and unblocked wells was calculated. The \%CV between the mean OD of blocked and unblocked wells was 0.242 . Likewise procedure was carried out for pooled -ve control serum and \% CV for mean OD of blocked and unblocked wells was 7.4 (table 6).

\subsubsection{Effect of skimmed milk on non-specific} blocking: Blocking step did not affect the outcome of the assay. But if the standardized procedure recommends the blocking step then the effect of 5\% skimmed milk as blocking buffer was demonstrated. For this instead of $1 \%$ BSA, a solution of $5 \%$ skimmed milk was made in PBS containing $0.5 \%$ Tween 20 . Assay was carried out with two serum samples i.e. in-house working standard (PS) and pooled -ve control serum sample. For both sera assay was carried out on different plates. Mean of OD, read at $450 \mathrm{~nm}$ was obtained and compared. For +ve serum sample the $\% \mathrm{CV}$ between mean OD of blocked wells (5\% skimmed milk and $1 \%$ BSA) was $5.9 \%$ while for ve serum sample the $\% \mathrm{CV}$ was found to be $22.5 \%$ (Table 6).

\begin{tabular}{|c|c|c|c|c|c|c|c|}
\hline $\begin{array}{c}\text { Sample } \\
\text { Dilution }\end{array}$ & \multicolumn{7}{|c|}{ Anti-Tetanus antibody concentration (IU\#/ml) } \\
\hline & PS $^{*}$ & $\mathbf{l}$ & $\mathbf{2}$ & $\mathbf{3}$ & $\mathbf{4}$ & $\mathbf{5}$ & $\mathbf{6}$ \\
\hline $\mathbf{1 : 6 4}$ & 18.77 & 1.0377 & 0.9765 & 0.6325 & 5.0543 & $>11.469$ & 1.9689 \\
\hline $\mathbf{1 : 1 2 8}$ & 17.72 & 1.2372 & 1.1888 & 0.8262 & 4.6980 & 18.815 & 1.8145 \\
\hline $\mathbf{1 : 2 5 6}$ & 16.82 & 1.0999 & 1.2054 & 0.7183 & 5.4718 & 22.677 & 2.1101 \\
\hline $\mathbf{1 : 5 1 2}$ & 19.77 & 1.1641 & 1.2891 & 0.8192 & 5.2253 & 23.531 & 2.2769 \\
\hline $\mathbf{1 : 1 0 2 4}$ & 17.74 & 0.8830 & 1.1534 & $<0.8830$ & 4.9051 & 21.647 & 2.4471 \\
\hline $\mathbf{1 : 2 0 4 8}$ & 17.39 & $<1.7659$ & $<1.7659$ & $<1.7659$ & 4.5022 & 20.937 & 2.2112 \\
\hline $\mathbf{1 : 4 0 9 6}$ & 17.75 & $<3.5319$ & $<3.5319$ & $<3.5319$ & $<3.5319$ & 23.286 & $<3.5319$ \\
\hline $\mathbf{1 : 8 1 9 2}$ & 18.75 & $<7.0638$ & $<7.0638$ & $<7.0638$ & $<7.0638$ & 22.580 & $<7.0638$ \\
\hline & & & & & & & \\
\hline Mean & 18.08 & 1.1347 & 1.1626 & 0.7491 & 4.9761 & 21.925 & 2.1381 \\
\hline SD & 0.880 & 0.0856 & 0.1154 & 0.09203 & 0.3524 & 1.6405 & 0.2255 \\
\hline \% CV & $\mathbf{4 . 8 6}$ & 7.5 & 9.9 & $\mathbf{1 2 . 2 8 5}$ & 7.0813 & 7.4 & $\mathbf{1 0 . 5 4 6}$ \\
\hline
\end{tabular}

Table 8 shows the parallelism in ELISA determined by calculating anti-tetanus antibodies concentration from different dilution levels of positive guinea pig sera. Serum samples were chosen randomly and in each assay In-house working standard (PS) with known unitage was included. It worked as a system control showing that unitage of other serum samples was not over or under estimated. *Pooled Sera, \#International Unit, ${ }^{\circledR}$ standard deviation, ${ }^{\$}$ coefficient of variation.

3.4.4. Linearity: It is the ability of the procedure to produce results that are directly proportional to the concentration of the analyte in the samples.

To verify the linearity of the assay, 6 randomly chosen guinea pig serum samples were tested, evaluated and compared with standard serum (PS) and with each other. Concentration-response plots (mean OD against log serum relative dilution) of the 6 individual sera and standard serum showed linear relationship. There was no significant divergence from each other. Moreover, with an increase in dilution there was a corresponding decrease in OD value and hence antibody concentration (Table 7). 
3.4.5. Parallelism: To demonstrate parallelism, the antibody concentrations were calculated from the mean OD of duplicate wells and corresponding dilution factor from different sample dilution levels for 6 test serum samples, chosen randomly and one +ve serum sample (PS). The mean antibody concentration of each sample determined from different dilutions had a CV <20\% (Table 8).

Each set of estimated concentrations from the serial dilutions of the same serum did not trend toward increasing or decreasing estimates of antibodies concentration over the range of dilutions. The $\mathrm{CVs}$ of IgG concentrations calculated from different dilution levels of the same serum ranged from $4.86 \%$ to $12.285 \%$ for all 6 serum samples (Table 8 ).

\section{Discussion}

For titration of tetanus antitoxin in sera of immunized animals, a double-dose single-dilution (DDSD) regime, to be used in AIM has been recommended [13]. The main problem with the DDSD method is the booster effects that are produced as a result of immunization on two occasions. Whenever an antigen is given for the first time, it is presented to B cells that later proliferates to form plasma cells and memory $\mathrm{B}$ cells. Plasma cells produce the immediate primary immune response while memory B cells are responsible for secondary antibody response. Memory B cells undergo affinity maturation, due to which antibodies of higher affinity are expressed on their surface, which enables them to be activated even by lower antigen levels. Once activated, memory B cells are able to produce antibody levels 100-1000 times higher than the levels attained in the primary response [23]. Hence a vaccine formulation, even of low antigenic content given on two occasions will pass the minimum requirement laid down by various authorities (Table 9). In the present study, for development of single-dilution-single-dose (SDSD) regime a three dilution assay was used. TNT performed in mice detects only the neutralizing antibodies while ELISA detects both neutralizing as well as non-neutralizing antibodies $[20,21] .6^{\text {th }}$ week $\mathrm{TN}$ titers were 5 times greater than $4^{\text {th }}$ week TN titers showing that from $4^{\text {th }}$ to $6^{\text {th }}$ week there was 5 fold increase in neutralizing antibody titer. At $4^{\text {th }}$ week ELISA/TNT ratio was 5:1 suggesting that concentration of non-neutralizing antibodies at $4^{\text {th }}$ week was about 5 times higher than neutralizing antibodies. However, at $6^{\text {th }}$ week the ratio became $1: 1$ indicating that at $6^{\text {th }}$ week post-immunization non-neutralizing antibodies die out as ELISA titer did not change despite 5 time increase in TN titers. Previously also, it has been demonstrated [20] that guinea pig sera at $6^{\text {th }}$ week after single immunization with tetanus toxoid showed similar TN and ELISA titers suggesting that when time post-immunization was increased from $4^{\text {th }}$ to $6^{\text {th }}$ week the titer of non-neutralizing antibodies decreased while that of neutralizing antibodies increased due to which ELISA correlated well with TNT at $6^{\text {th }}$ week post-immunization.

In the present study $\mathrm{TN}$ titers at all the dilutions were substantially above the minimum protective levels $[6,7]$ but since the immune response at third dilution fell abruptly there was doubt about use of middle dilution in SDSD regime. Hence $1^{\text {st }}$ dilution containing half the SHD of test vaccine and $40 \mathrm{IU} / \mathrm{ml}$ of the standard TT has been suggested for immunization of guinea pigs. Even though in different studies, for bleeding the immunized animals, different time intervals have been studied but it was shown that ELISA titers of sera before $6^{\text {th }}$ week of immunization determined against hyper immune reference serum did not show a true picture of neutralizing antibody levels [20]. Hence $6^{\text {th }}$ week postimmunization was chosen as bleeding time for sera raising. However, to save 14 days if bleeding is to be done at $4^{\text {th }}$ week, after thorough standardization studies, a factor could be calculated between ELISA and TNT that could be applied to ELISA titers e.g. in present study at $4^{\text {th }}$ week after immunization with $1 / 4$ dilution of toxoid preparation $(40 \mathrm{IU} / \mathrm{ml})$ the anti-tetanus antitoxin requirements in terms of ELISA titers should be 5 times higher than TN titers. 


\begin{tabular}{|c|c|c|}
\hline \multicolumn{3}{|c|}{ Requirements for Potency of Tetanus component } \\
\hline & Method & Requirement \\
\hline \multirow{3}{*}{$\mathrm{WHO}^{\alpha}$} & Challenge Assay in guinea pigs & Potency shall be \\
\hline & a) Guinea pigs & 1) $>40 \mathrm{IU} / \mathrm{SHD}$ \\
\hline & b) Mice & $\begin{array}{l}\text { 1) } \geq 40 \mathrm{IU} / \mathrm{SHD} \\
\text { 2) } \geq 60 \mathrm{IU} / \mathrm{SHD}(\mathrm{DTP})\end{array}$ \\
\hline \multirow[t]{2}{*}{$\mathbf{E P}^{\beta}$} & $\begin{array}{c}\text { Challenge Assay paralytic dose } \\
\text { 1) Guinea pig }\end{array}$ & $\begin{array}{l}\text { Lower confidence limit not less } \\
\text { than } 40 \text { units/SHD } \\
\text { 1) } 40 \mathrm{IU} / \mathrm{SHD}\end{array}$ \\
\hline & 2) Mice & $\begin{array}{l}\text { 1) } 40 \mathrm{IU} / \mathrm{SHD} \\
\text { 2) } 60 \mathrm{IU} / \mathrm{SHD}(\mathrm{DTP})\end{array}$ \\
\hline USPG & $\begin{array}{l}\text { 1) Immunization of Guinea pigs } \\
\text { 2) Bleeding (not later than } 6 \text { weeks) } \\
\text { 3) TNT test (mice) }\end{array}$ & $\begin{array}{l}\text { Antibody level should be at least } 2 \\
\text { IU/ml of Tetanus antitoxin. }\end{array}$ \\
\hline \multirow[b]{3}{*}{$\mathrm{BP}^{*}$} & $\begin{array}{l}\text { Challenge method } \\
\text { 1) Guinea pig }\end{array}$ & 1) $\geq 40 \mathrm{IU} / \mathrm{SHD}$ \\
\hline & 2) mice & $\begin{array}{l}\text { 1) } \geq 40 \mathrm{IU} / \mathrm{SHD} \\
\text { 2) } \geq 60 \mathrm{IU} / \mathrm{SHD} \text { (DTP) }\end{array}$ \\
\hline & $\begin{array}{l}\qquad \text { AIM }^{\ddagger} \\
\text { 1) Immunization of Guinea pigs } \\
\text { 2) Bleeding } \\
\text { (not later than } 2 \text { weeks after } 2^{\text {nd injection, if }} \\
\text { two injections are given) } \\
\text { (not later than } 6 \text { weeks after single injection) } \\
\text { 3) TNT test (mice) }\end{array}$ & $\begin{array}{l}\text { The antibody of each of no fewer } \\
\text { than } 2 / 3 \text { rd of g. pigs contains not } \\
\text { less than } 0.05 \text { units of TAT/ml or, } \\
\text { alternatively the serum of each of } \\
\text { no fewer than } 1 / 3^{\text {rd }} \text { of the g. pigs } \\
\text { contains not less than } 0.5 \mathrm{unit} / \mathrm{ml}\end{array}$ \\
\hline \multirow{3}{*}{ IP $^{\#}$} & $\begin{array}{l}\text { Challenge method } \\
\text { 1) Guinea pig }\end{array}$ & $\begin{array}{l}\text { Lower confidence limit not less } \\
\text { than } 40 \text { units/SHD } \\
\text { 1) } \geq 40 \mathrm{IU} / \mathrm{SHD}\end{array}$ \\
\hline & 2) mice & $\begin{array}{l}\text { 1) } \geq 40 \mathrm{IU} / \mathrm{SHD} \\
\text { 2) } \geq 60 \mathrm{IU} / \mathrm{SHD}(\mathrm{DTP})\end{array}$ \\
\hline & $\begin{array}{l}\qquad \text { AIM }^{\ddagger} \\
\text { 1) Immunization of Guinea pigs } \\
\text { 2) Bleeding (not later than } 2 \text { weeks after } 2^{\text {nd }} \\
\text { immunization) } \\
\text { 3) TNT test (mice) }\end{array}$ & $\begin{array}{l}\text { Antibody level should be at least } \geq \\
0.5 \mathrm{IU} / \mathrm{SHD} \text { of Tetanus } \\
\text { Antitoxin/ml in at least sera of } 6 \\
\text { guinea pigs out of } 9\end{array}$ \\
\hline
\end{tabular}

Table 9 shows the comparative requirements for potency of tetanus component as laid down by various regulatory authorities. ${ }^{\alpha}$ World Health Organization, ${ }^{\beta}$ Europian Pharmacopoeia, ${ }^{\circledR}$ United States Pharmacopoeia, *British Pharmacopoeia, "Indian Pharmacopoeia.

Indirect ELISA was found to be highly sensitive for anti-tetanus antibody detection. The sensitivity was $0.0002 \mathrm{IU} / \mathrm{ml}$, while LOQ was $0.0005 \mathrm{IU} / \mathrm{ml}$. Also, the ELISA was of high validity. It could be used with high success rates without affecting the sensitivity even if there were slight changes in the assay procedure caused deliberately or due to human error. Hence, as has been noted by WHO working group [24] that alternative validated method could be used for potency determination of toxoid vaccines, ELISA can be used as an alternative for the TNT. 
Moreover, by use of ELISA, mice used in TNT were saved besides saving 5 days required for antibody titration in TNT.

The results of this study clearly demonstrate that replacing the DDSD assay by SDSD assay is acceptable. To best of our knowledge, this is the first study that addresses the problem of 'booster effects' in AIM and tries to investigate single dose regime. Moreover, to further decrease usage of animals as suggested elsewhere [18, 24] ELISA is a viable replacement method for antibody titration as recommended by WHO [10]. Even though use of alternative methods for potency estimation has been recommended $[10,25]$, there is not sufficient information and data available in regard to validation of these methods. Hence, present study contributes significantly in providing experimental evidence in favour of alternate methods.

\section{References}

1. Vandelaer, J.; Birmingham. M.; Gasse. F.; Kurian, M.; Shaw, C.; Garnier, S. Tetanus in developing countries: an update on the maternal and neonatal tetanus elimination initiative, Vaccine, 2003, 21, 3442-3445. doi: 10.1016/S0264-410X(03)00347-5.

2. Griffiths, U.K.; Wolfson, L.J.; Quddus, A.; Younus, M.; Hafiz, R.A. Incremental costeffectiveness of supplementary immunization activities to prevent neonatal tetanus in Pakistan. Bull World Health Organ, 2004, 82, 643-651. PMID: 15628201 [PubMed- indexed for Medline].

3. UNICEF, WHO, UNFPA. Maternal and neonatal tetanus elimination by 2005 . Strategies for achieving and maintaining elimination 2000, 1-14. [http://www.unicef.org/immunization/files/M NTE_strategy_paper.pdf].

4. World Health Organization. Neonatal tetanus, Bull World Health Organ, 1998, 76(2), 135. [http://whqlibdoc.who.int/bulletin/1998/supple ment2/bulletin_1998_76(supp2)_116-162.pdf.

5. World Health Organization. Progress towards the global elimination of neonatal tetanus, 1990-1998, Wkly Epidemiol, 1999, Rec. 74, 73-80.
6. Centers for Disease Control and Prevention. Epidemiology and Prevention of VaccinePreventable Diseases. Atkinson, W.; Hamborsky, J.; McIntyre, L.; Wolfe, S. Eds.; 10th Ed. 2nd printing, Washington DC: Public Health Foundation, 2008. [http://www.cdc.gov/niP/publications/pink/ tetanus.pdf].

7. World Health Organization. Expanded programme on immunization basis for immunization. Module 3: Tetanus. WHO Document, WHO/EPI/GEN/93.13, 1993, 1-22. [http://whqlibdoc.who.int/hq/1993/WHO_EPI GEN_93.13_mod3.pdf].

8. Bytchenko, B. Microbiology of tetanus. Cited from: Tetanus: Important New Concepts. Veronesi, R. Ed.; Amsterdam, Excerpta Medica, 1981, pp28-39.

9. Bizzini, B. Tetanus, In: Bacterial vaccines. Germanier, R. Ed.; Acadamic Press, Orlando, Florida, 1984, pp37-67.

10. World Health Organization. Recommendations for diphtheria, tetanus, pertussis and combined vaccines (Amendments 2003) Annex 5, WHO Technical Report Series, 2005, 927, 138-147.

11. Castle P. Alternatives to animal testing: achievements and recent developments in the European Pharmacopoeia, Dev Biol Stand, 1996,86:21-29.

12. British Pharmacopoeia. Tetanus Vaccine. 2003, III, 2821.

13. Indian Pharmacopoeia. Tetanus Toxoid. 1996, II, 741-744.

14. World Health Organization. Manual for the production and control of vaccines: Tetanus Toxoid. Geneva: WHO (BLG/UNDP/77.2 Rev.1), 1977, 78-79.

15. World Health Organization. Traditional methods for testing the potency of vaccines containing adsorbed diphtheria and tetanus toxoid. WHO/VSQ/97.04, 1997, III, 45.

16. World Health Organization. Validation of potency assays for toxoid vaccines based on in-vitro methods of measuring antiserum in the sera of vaccinated animals. WHO/ VSQ / 97.04, 1997, III, 175.

17. Winsnes, R., and Hendriksen, C. Collaborative study for the validation of serological methods for potency testing of tetanus toxoid vaccines 
for human use. Pharmeuropa Bio 2004-2, 2003, 5.

18. Sesardic, D. Alternative to challenge assays in animals for vaccine control: Establishment of Diphetheria potency assays based on serological methods. Alternative to challenge assays in animals for vaccine control. Directorate for quality of medicines, (EDQM), Council of Europe, Budapest, Hungary, 6-7 $7^{\text {th }}$ October, 2004.

19. Sesardic, D.; Winsnes, R.; Ringsby, P.; BehrGross, M-E. Collaborative study for the validation of serological methods for potency testing of diphtheria toxoid vaccines. Extended study: correlation of serology with in vitro toxin neutralization, PHARMEUROPA BIO 2003(2), 2004, 69-75.

20. Gupta, R.K.; Siber, G.R. Comparative analysis of tetanus antitoxin titers of sera from immunized mice and guinea pigs determined by toxin neutralization test and enzyme linked immunosorbent assay. Biologicals, 1994, 22, 215-219.

21. Gupta, R.K.; Siber, G.R. Use of in-vitro Vero cell assay and ELISA in the United States:
Potency test of vaccines containing adsorbed Diphtheria and Tetanus Toxoids, Dev Biol Stand, 1996, 86, 207-215. PMID: 8785950 [PubMed - indexed for MEDLINE).

22. Richardson, M.D. Computer - Assisted Rapid Enzyme Linked Immunosorbent Assay (ELISA) in the serological diagnosis of Aspergillosis, J Immunol Methods, 1983, 56, 201-207. PMID: 6402546 [PubMed - indexed for MEDLINE).

23. Kuby J. Generation of the humoral immune response. In Immunology, $3^{\text {rd }}$ (edn.).; W.H. Freeman and Co., New York, 1997, pp323.

24. WHO Working Group on revision of the Manual of Laboratory Methods for Testing DTP Vaccines-Report of two meetings held on 20-21 July 2006 and 28-30 March 2007, Geneva, Switzerland, Vaccine, 2008, 26, 19131921.

25. European Pharmacopoeia. Assay of tetanus vaccine (adsorbed). In: European Pharmacopoeia, 2005, 5.0, 198-202. 